\title{
The MAREDAT global database of high performance liquid chromatography marine pigment measurements
}

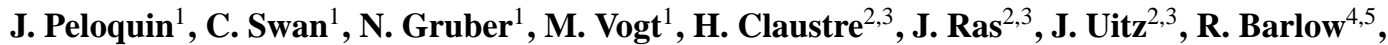 \\ M. Behrenfeld ${ }^{6}$, R. Bidigare ${ }^{7}$, H. Dierssen ${ }^{8}$, G. Ditullio ${ }^{9}$, E. Fernandez ${ }^{10}$, C. Gallienne $^{11}$, S. Gibb ${ }^{12}$, \\ R. Goericke ${ }^{13}$, L. Harding ${ }^{14}$, E. Head ${ }^{15}$, P. Holligan ${ }^{16}$, S. Hooker ${ }^{17}$, D. Karl ${ }^{7}$, M. Landry ${ }^{7}$, R. Letelier ${ }^{18}$, \\ C. A. Llewellyn ${ }^{11}$, M. Lomas $^{19}$, M. Lucas $^{5}$, A. Mannino ${ }^{17}$, J.-C. Marty ${ }^{2,3}$, B. G. Mitchell ${ }^{13}$, \\ F. Muller-Karger ${ }^{20}$, N. Nelson ${ }^{21}$, C. O'Brien ${ }^{1}$, B. Prezelin ${ }^{22}$, D. Repeta ${ }^{23}$, W. O. Smith Jr. ${ }^{24}$, \\ D. Smythe-Wright ${ }^{16}$, R. Stumpf ${ }^{25}$, A. Subramaniam ${ }^{26}$, K. Suzuki ${ }^{27}$, C. Trees $^{28}$, M. Vernet $^{13}$, \\ N. Wasmund ${ }^{29}$, and S. Wright ${ }^{30}$ \\ ${ }^{1}$ Environmental Physics Group, Institute of Biogeochemistry and Pollutant Dynamics, ETH Zürich, Switzerland \\ ${ }^{2}$ Laboratoire d'Océanographie de Villefranche, UMR7093, CNRS, 06230 Villefranche-sur-Mer, France \\ ${ }^{3}$ Université Pierre et Marie Curie-Paris 6, UMR7093, Laboratoire d'Océanographie de Villefranche, \\ 06230 Villefranche-sur-Mer, France \\ ${ }^{4}$ Bayworld Centre for Research and Education, Rogge Bay 8012, Cape Town, South Africa \\ ${ }^{5}$ Marine Research Institute, University of Cape Town, Rondebosch 7701, Cape Town, South Africa \\ ${ }^{6}$ Department of Botany and Plant Pathology, Oregon State University, Corvallis, OR, USA \\ ${ }^{7}$ Department of Oceanography, University of Hawai'i at Manoa, Honolulu, HI, USA \\ ${ }^{8}$ Department of Marine Sciences, University of Connecticut, Groton, CT, USA \\ ${ }^{9}$ Grice Marine Lab, College of Charleston, SC, USA \\ ${ }^{10}$ Departamento Ecoloxía e Bioloxía Animal, Universidade de Vigo, 36310 Vigo, Spain \\ ${ }^{11}$ Plymouth Marine Laboratory, Plymouth, PL1 3DH, UK \\ ${ }^{12}$ Environmental Research Institute, University of the Highlands and Islands, UK \\ ${ }^{13}$ Scripps Institution of Oceanography, University of California, San Diego, CA, USA \\ ${ }^{14}$ University of Maryland Horn Point Laboratory, Cambridge, MD, USA \\ ${ }^{15}$ Ecosystem Research Division, Bedford Institute of Oceanography, Dartmouth, Nova Scotia, Canada \\ ${ }^{16}$ Ocean and Earth Science University of Southampton, National Oceanography Centre, Southampton, \\ SO14 3ZH, UK \\ ${ }^{17}$ NASA Goddard Space Flight Center, Greenbelt, MD, USA \\ ${ }^{18}$ College of Oceanic and Atmospheric Sciences, Oregon State University, Corvallis, OR, USA \\ ${ }^{19}$ Bermuda Institute of Ocean Sciences, St. George's GE 01, Bermuda \\ ${ }^{20}$ Institute for Marine Remote Sensing/IMaRS, College of Marine Science, University of South Florida, \\ St. Petersburg, FL, USA \\ ${ }^{21}$ Earth Research Institute, University of California, Santa Barbara, CA, USA \\ ${ }^{22}$ Department of Ecology, Evolution and Marine Biology, University of California, Santa Barbara, CA, USA \\ ${ }^{23}$ Woods Hole Oceanographic Institution, Woods Hole, MA, USA \\ ${ }^{24}$ Virginia Institute of Marine Science, College of William \& Mary, Gloucester Pt., VA, USA \\ ${ }^{25}$ NOAA National Ocean Service, Silver Spring, MD, USA \\ ${ }^{26}$ Lamont Doherty Earth Observatory at Columbia University, Palisades, NY, USA \\ ${ }^{27}$ Environmental Earth Science, Hokkaido University, Sapporo 060-0810, Japan \\ ${ }^{28}$ NATO Undersea Research Centre, La Spezia, Italy \\ ${ }^{29}$ Leibniz Institute for Baltic Sea Research, 18119 Warnemünde, Germany \\ ${ }^{30}$ Australian Antarctic Division, and Antarctic Climate and Ecosystems Cooperative Research Centre, \\ 203 Channel Hwy Kingston, Tasmania 7050, Australia
}

Correspondence to: C. Swan (chantal.swan@usys.ethz.ch) 
Abstract. A global pigment database consisting of 35634 pigment suites measured by high performance liquid chromatography was assembled in support of the MARine Ecosytem DATa (MAREDAT) initiative. These data originate from 136 field surveys within the global ocean, were solicited from investigators and databases, compiled, and then quality controlled. Nearly one quarter of the data originates from the Laboratoire d'Océanographie de Villefranche (LOV), with an additional $17 \%$ and $19 \%$ stemming from the US JGOFS and LTER programs, respectively. The MAREDAT pigment database provides high quality measurements of the major taxonomic pigments including chlorophylls $a$ and $b, 19$ '-butanoyloxyfucoxanthin, 19'hexanoyloxyfucoxanthin, alloxanthin, divinyl chlorophyll $a$, fucoxanthin, lutein, peridinin, prasinoxanthin, violaxanthin and zeaxanthin, which may be used in varying combinations to estimate phytoplankton community composition. Quality control measures consisted of flagging samples that had a total chlorophyll $a$ concentration of zero, had fewer than four reported accessory pigments, or exceeded two standard deviations of the log-linear regression of total chlorophyll $a$ with total accessory pigment concentrations. We anticipate the MAREDAT pigment database to be of use in the marine ecology, remote sensing and ecological modeling communities, where it will support model validation and advance our global perspective on marine biodiversity. The original dataset together with quality control flags as well as the gridded MAREDAT pigment data may be downloaded from PANGAEA: http://doi.pangaea.de/10. 1594/PANGAEA.793246.

\section{Introduction}

The recognition of the role of phytoplankton functional groups in controlling the biogeochemical cycles of critical elements has created a need to constrain the global distribution and abundance of these groups (Doney et al., 2009; Weber and Deutsch, 2010, 2012). Marine ecosystem modelers now estimate multiple phytoplankton functional types (PFTs) within biogeochemical models, but until recently there existed very limited data with which to evaluate the modeled PFTs (Le Quéré et al., 2005; Hood et al., 2006; Anderson, 2005; Buitenhuis et al., 2012b). Great promise lies with indirect estimates of phytoplankton classes from satellite retrievals. Fields of chlorophyll and/or biomass specific to PFTs (Alvain et al., 2005, 2008; Raitsos et al., 2008; Demarcq et al., 2012) or to different size classes of phytoplankton (Ciotti and Bricaud, 2006; Uitz et al., 2006; Hirata et al., 2008, 2011; Kostadinov et al., 2009; Brewin et al., 2010) can be quantified via remote sensing methods. However, at present these methods lack sufficient global validation datasets, and are restricted to the surface ocean.

Depth resolved phytoplankton community structure can be determined in field samples through electron or light mi- croscopy, flow cytometry, genetic analysis or high performance liquid chromatography (HPLC). Microscopy and genomics allow for direct identification of algal species and morphology; however, these methods are time-consuming for large-scale surveys, and certain types of taxa or features (e.g., flagella) may be lost or damaged depending on preservation and handling (Havskum et al., 2004). Flow cytometry allows for high sample throughput and information on size and pigment content, but is limited to the smaller size classes of plankton (Li and Wood, 1988). On the contrary, HPLC allows for a high sample throughput and yields pigment concentrations covering all size ranges that may be chemotaxonomically interpreted to quantify marine phytoplankton community composition (Mackey et al., 1996; Van den Meersche et al., 2008; Wright et al., 2010; Hirata et al., 2011). Furthermore, pigments are relatively frequently sampled during various oceanographic field campaigns. HPLC thus yields a data product with large potential, particularly given its advantage over satellite methods for resolving depth distribution.

Several of the major accessory pigments can provide a rough indication of the presence of specific taxonomic groups and size fractions (Vidussi et al., 2001), although a recent review has indicated that relatively few of these pigments are specific to individual phytoplankton taxa (Higgins et al., 2011). For this reason, methods employing the chemotaxonomic identification of pigment ratios specific to algal classes are recommended for interpretation of pigment data. Identification usually involves a method that determines the overall pigment structure as a linear sum of contributions from all groups, and then attempts to estimate these contributions through an (inverse) optimization method, such as is implemented in the widely used CHEMTAX program (Mackey et al., 1996). Alternative, more direct, but also less quantitative methods include the association of PFTs with certain pigment ratios that are unique for a particular group (Claustre, 1994; Uitz et al., 2006). In all cases, the pigment data need to be of high quality and consistent across all considered pigments.

We have combined 136 independent field datasets totaling 35634 quality-controlled HPLC pigment suites from the world ocean for the MARine Ecosytem DATa (MAREDAT) initiative (Table 1). The largest fraction $(22 \%)$ was contributed by the Laboratoire d'Océanographie de Villefranche (LOV). Additional major contributions were made by the Palmer LTER project (19\%), the US JGOFS program (17\%), the collective US BATS and HOT time series (13\%), and the AMT cruises (14\%), with the remaining significant fraction coming from individual investigators and cruises (see Table 1). The data cover nearly two decades and extend over a wide range of trophic regimes from extremely oligotrophic to near-coastal eutrophic. MAREDAT pigment data include both HPLC-derived chlorophyll $a$ and accessory pigments (e.g., chlorophyll $b, 19$ '-butanoyloxyfucoxanthin, 19' hexanoyloxyfucoxanthin, alloxanthin, divinyl chlorophyll $a$, 
Table 1. Summary of pigment sample contributions to MAREDAT. $N_{\mathrm{QC}}$ represents the number of quality-controlled samples each contribution submitted to the dataset. $F_{\text {Rat }}$ represents the percentage of samples that were removed due to values outlying two standard deviations of the TCHLA vs. TACC linear relation. DS represents the data source, for which numerical values correspond to definitions below the table.

\begin{tabular}{|c|c|c|c|c|c|c|c|c|}
\hline No. & Investigator & Program & Cruise & $N_{\mathrm{QC}}$ & $F_{\text {Rat }}(\%)$ & DS & HPLC method & Data reference \\
\hline 1 & Ras, J. and H. Claustre & BIOSOPE & Biosope & 635 & 0 & 1 & LOV-D & Ras et al. (2008) \\
\hline 2 & Claustre, H. and J.-C. Marty & FRONTAL & ALMOFRONT 1 & 247 & 0 & 16 & LOV-A & $\begin{array}{l}\text { Claustre et al. (1994a, b); } \\
\text { Claustre (1994) }\end{array}$ \\
\hline 3 & Claustre, H. and J.-C. Marty & FRONTAL & ALMOFRONT2 & 430 & 0 & 16 & LOV-B & Uitz et al. (2006) \\
\hline 4 & Claustre, $\mathrm{H}$. & BENCAL & BENCAL & 47 & 0 & 12 & LOV-C & Morel et al. (2006) \\
\hline 5 & Claustre, H. and J.-C. Marty & Eumeli & Cruise 3 & 172 & 0 & 12 & LOV-A & $\begin{array}{l}\text { Claustre and Marty } \\
\text { (1995); Claustre (1994) }\end{array}$ \\
\hline 6 & Claustre, $\mathrm{H}$. & Eumeli & Cruise 4 & 228 & 0 & 14 & LOV-A & $\begin{array}{l}\text { Claustre and Marty } \\
\text { (1995); Claustre (1994) }\end{array}$ \\
\hline 7 & Claustre, $\mathrm{H}$. & & METEOR 31/1 & 722 & 0.1 & 12 & LOV-B & $\begin{array}{l}\text { Vidussi et al. (2001); } \\
\text { Uitz et al. (2006) }\end{array}$ \\
\hline 8 & Claustre, $\mathrm{H}$. & MINOS & MINOS & 768 & 0 & 12 & LOV-B & Uitz et al. (2006) \\
\hline 9 & Claustre, H. and J.-C. Marty & OLIPAC & & 508 & 0 & 12 & LOV-B & Uitz et al. (2006) \\
\hline 10 & Claustre, $\mathrm{H}$. & POMME1 & Leg 1 & 529 & 2.8 & 12 & LOV-C & $\begin{array}{l}\text { Claustre et al. (2005); } \\
\text { Uitz et al. (2006) }\end{array}$ \\
\hline 11 & Claustre, $\mathrm{H}$. & POMME1 & Leg 2 & 146 & 0 & 12 & LOV-C & $\begin{array}{l}\text { Claustre et al. (2005); } \\
\text { Uitz et al. (2006) }\end{array}$ \\
\hline 12 & Claustre, $\mathrm{H}$. & POMME2 & Leg 1 & 609 & 4.4 & 12 & LOV-C & $\begin{array}{l}\text { Claustre et al. (2005); } \\
\text { Uitz et al. (2006) }\end{array}$ \\
\hline 13 & Claustre, $\mathrm{H}$. & POMME2 & Leg 2 & 78 & 0 & 12 & LOV-C & $\begin{array}{l}\text { Claustre et al. (2005); } \\
\text { Uitz et al. (2006) }\end{array}$ \\
\hline 14 & Claustre, $\mathrm{H}$. & POMME3 & Leg 1 & 526 & 3.7 & 12 & LOV-C & $\begin{array}{l}\text { Claustre et al. (2005); } \\
\text { Uitz et al. (2006) }\end{array}$ \\
\hline 15 & Claustre, $\mathrm{H}$. & POMME3 & Leg 2 & 88 & 0 & 12 & LOV-C & $\begin{array}{l}\text { Claustre et al. (2005); } \\
\text { Uitz et al. (2006) }\end{array}$ \\
\hline 16 & Claustre, H. and J.-C. Marty & PROSOPE & PROSOPE & 475 & 0.2 & 15 & LOV-C & Uitz et al. (2006) \\
\hline 17 & Marty, J.-C. & DYFAMED Time Series & & 1400 & 0.1 & 12 & LOV-ABCD & Marty et al. (2002) \\
\hline 18 & Claustre, $\mathrm{H}$. & ANTARES & Cruise 2 & 133 & 0 & 13 & LOV-A & $\begin{array}{l}\text { Claustre et al. (2005); } \\
\text { Uitz et al. (2006) }\end{array}$ \\
\hline 19 & Claustre, $\mathrm{H}$. & CATCH & & 163 & 0 & 12 & LOV-B & Uitz et al. (2006) \\
\hline 20 & DiTullio, G. & & Peru Upwelling & 345 & 0.9 & 2 & & DiTullio et al. (2005) \\
\hline 21 & Letelier, R. & US GLOBEC & NEP & 0 & 41.8 & 3 & & Letelier (2007) \\
\hline 22 & Letelier, R. & US GLOBEC & NEP & 0 & 37.5 & 3 & & Letelier (2007) \\
\hline 23 & Bidigare, $\mathrm{R}$. & US JGOFS AESOPS & Ross Sea Process 1 & 0 & 42.6 & 4 & & Bidigare (2010a) \\
\hline 24 & Bidigare, $\mathrm{R}$. & US JGOFS AESOPS & Ross Sea Process 2 & 136 & 0.7 & 4 & & Bidigare (2010b) \\
\hline 25 & Bidigare, $\mathrm{R}$. & US JGOFS AESOPS & Ross Sea Process 3 & 64 & 10.7 & 4 & & Bidigare (2010c) \\
\hline 26 & Bidigare, $\mathrm{R}$. & US JGOFS AESOPS & Ross Sea Process 4 & 167 & 0 & 4 & & Bidigare (2010d) \\
\hline 27 & Goericke, R. & US JGOFS AESOPS & APFZ Survey 1 & 39 & 0 & 4 & & Goericke (2010a) \\
\hline 28 & Goericke, R. & US JGOFS AESOPS & APFZ Process 1 & 94 & 0 & 4 & & Goericke (2010b) \\
\hline 29 & Goericke, R. & US JGOFS AESOPS & APFZ Survey 2 & 48 & 0 & 4 & & Goericke (2010c) \\
\hline 30 & Goericke, R. & US JGOFS AESOPS & APFZ Process 2 & 88 & 4.3 & 4 & & Goericke (2010d) \\
\hline 31 & Karl, D. & HOT Time Series & & 2008 & 1.0 & 5 & & \\
\hline 32 & Lomas, M. & BATS Time Series & & 2778 & 2.5 & 6 & & \\
\hline 33 & Goericke, R. & US JGOFS Arabian Sea & Process Cruise 1 & 681 & 4.5 & 4 & & Goericke (2010e) \\
\hline 34 & Bidigare, $\mathrm{R}$. & US JGOFS Arabian Sea & Process Cruise 2 & 432 & 0.4 & 4 & & Bidigare (2010e) \\
\hline 35 & Goericke, R. & US JGOFS Arabian Sea & Process Cruise 4 & 716 & 1.3 & 4 & & Goericke (2010f) \\
\hline 36 & Bidigare, R. & US JGOFS Arabian Sea & Process Cruise 5 & 522 & 0.2 & 4 & & Bidigare (2010f) \\
\hline 37 & Bidigare, $\mathrm{R}$. & US JGOFS Arabian Sea & Process Cruise 6 & 542 & 1.0 & 4 & & Bidigare (2010g) \\
\hline 38 & Goericke, R. & US JGOFS Arabian Sea & Process Cruise 7 & 519 & 0.7 & 4 & & Goericke (2010g) \\
\hline 39 & Bidigare, $\mathrm{R}$. & US JGOFS Equatorial Pacfic & Spring Survey & 588 & 0 & 4 & & Bidigare $(2010 \mathrm{~h})$ \\
\hline 40 & Bidigare, $\mathrm{R}$. & US JGOFS Equatorial Pacfic & Spring Time Series & 341 & 0 & 4 & & Bidigare (2010i) \\
\hline 41 & Bidigare, $\mathrm{R}$. & US JGOFS Equatorial Pacfic & Fall Survey & 508 & 0 & 4 & & Bidigare $(2010 \mathrm{j})$ \\
\hline 42 & Bidigare, $\mathrm{R}$. & US JGOFS Equatorial Pacfic & Fall Time Series & 297 & 0 & 4 & & Bidigare (2010k) \\
\hline 43 & Repeta, D. & US JGOFS NABE & & 247 & 7.2 & 4 & & Repeta (2010) \\
\hline 44 & Barlow, R. & & ARABESQUE & 610 & 2.7 & 7 & & \\
\hline 45 & Llewellyn, C. & & BOFS & 50 & 0 & 7 & & \\
\hline 46 & Barlow, R. & & BOFS & 272 & 3.5 & 7 & & \\
\hline 47 & Barlow, R. & & BOFS & 88 & 1.1 & 7 & & \\
\hline 48 & Cummings, D. & & HPLC & 247 & 1.6 & 7 & & \\
\hline 49 & Smythe-Wright, D. & & HPLC & 336 & 4.6 & 7 & & \\
\hline 50 & Lucas, M. & & HPLC & 50 & 2.0 & 7 & & \\
\hline 51 & Smythe-Wright, D. & & HPLC2 & 369 & 0.8 & 7 & & \\
\hline 52 & Cummings, D. & & HPLC2 & 256 & 1.5 & 7 & & \\
\hline 53 & Lucas, M. & & HPLC2 & 50 & 2.0 & 7 & & \\
\hline 54 & Vernet, $\mathrm{M}$. & Palmer Station LTER & 001pal & 0 & 57.7 & 8 & & Kozlowski et al. (2011) \\
\hline 55 & Prezelin, B. & Palmer Station LTER & 9394pal & 359 & 1.4 & 8 & & \\
\hline 56 & Prezelin, B. & Palmer Station LTER & 9495pal & 313 & 3.4 & 8 & & Kozlowski et al. (2011) \\
\hline 57 & Vernet, $\mathrm{M}$. & Palmer Station LTER & 9596pal & 377 & 1.0 & 8 & & Kozlowski et al. (2011) \\
\hline
\end{tabular}


Table 1. Continued.

\begin{tabular}{|c|c|c|c|c|c|c|c|c|}
\hline No. & Investigator & Program & Cruise & $N_{\mathrm{QC}}$ & $F_{\text {Rat }}(\%)$ & DS & HPLC method & Data reference \\
\hline 58 & Vernet, $\mathrm{M}$. & Palmer Station LTER & 9798pal & 126 & 27.2 & 8 & & Kozlowski et al. (2011) \\
\hline 59 & Vernet, $\mathrm{M}$. & Palmer Station LTER & $9900 \mathrm{pal}$ & 235 & 7.8 & 8 & & Kozlowski et al. (2011) \\
\hline 60 & Vernet, $\mathrm{M}$. & Palmer Station LTER & $9899 \mathrm{pal}$ & 139 & 1.4 & 8 & & Kozlowski et al. (2011) \\
\hline 61 & Prezelin, B. & Palmer Station LTER & hplc_mar_93 & 535 & 7.1 & 8 & & \\
\hline 62 & Vernet, M. & Palmer Station LTER & $\operatorname{lmg} 001$ & 235 & 7.7 & 8 & & Kozlowski et al. (2011) \\
\hline 63 & Vernet, M. & Palmer Station LTER & $\operatorname{lmg} 101$ & 0 & 61.2 & 8 & & Kozlowski et al. (2011) \\
\hline 64 & Vernet, $\mathrm{M}$. & Palmer Station LTER & $\operatorname{lmg} 301$ & 406 & 0 & 8 & & Kozlowski et al. (2011) \\
\hline 65 & Vernet, $\mathrm{M}$. & Palmer Station LTER & $\operatorname{lmg} 401$ & 0 & 85.5 & 8 & & Kozlowski et al. (2011) \\
\hline 66 & Vernet, $\mathrm{M}$. & Palmer Station LTER & $\operatorname{lmg} 601$ & 408 & 1.0 & 8 & & Kozlowski et al. (2011) \\
\hline 67 & Vernet, $\mathrm{M}$. & Palmer Station LTER & $\operatorname{lmg} 9801$ & 187 & 3.1 & 8 & & Kozlowski et al. (2011) \\
\hline 68 & Vernet, M. & Palmer Station LTER & lmg9901 & 355 & 3.0 & 8 & & Kozlowski et al. (2011) \\
\hline 69 & Prezelin, B. & Palmer Station LTER & pd9401 & 408 & 5.4 & 8 & & Kozlowski et al. (2011) \\
\hline 70 & Vernet, M. & Palmer Station LTER & pd9701 & 588 & 1.3 & 8 & & Kozlowski et al. (2011) \\
\hline 71 & Prezelin, B. & Palmer Station LTER & pd9109 & 302 & 9.2 & 8 & & \\
\hline 72 & Prezelin, B. & Palmer Station LTER & pd9301 & 651 & 0.9 & 8 & & \\
\hline 73 & Prezelin, B. & Palmer Station LTER & pd9307 & 319 & 0 & 8 & & \\
\hline 74 & Vernet, $\mathrm{M}$. & Palmer Station LTER & pd9501 & 401 & 5.8 & 8 & & Kozlowski et al. (2011) \\
\hline 75 & Vernet, M. & Palmer Station LTER & pd9601 & 528 & 0.2 & 8 & & Kozlowski et al. (2011) \\
\hline 76 & Marty, J.-C. & ANTARES & Cruise 3 & 43 & 0 & 9 & & $\begin{array}{l}\text { Marty (2004), } \\
\text { doi:10.1594/PANGAEA. } \\
136858\end{array}$ \\
\hline 77 & Wasmund, $\mathrm{N}$. & BASYS & BASYS I (1996) & 17 & 19.2 & 9 & & $\begin{array}{l}\text { Wasmund (2006), } \\
\text { doi:10.1594/PANGAEA } \\
\text { 399756, 399758-61 }\end{array}$ \\
\hline 78 & Head, E. & & BAF 89-3 & 28 & 0 & 9 & & $\begin{array}{l}\text { Head (2002), } \\
\text { doi:10.1594/PANGAEA. } \\
808261\end{array}$ \\
\hline 79 & Barlow, R. & NERC BOFS & North Atlantic & 59 & 1.6 & 9 & & $\begin{array}{l}\text { Lowry; BODC (2004), } \\
\text { doi:10.1594/PANGAEA. } \\
\text { 198134, 198151, } \\
198417,198419\end{array}$ \\
\hline 80 & Nelson, $\mathrm{N}$. & AMMA & amma-rb-06 & 9 & 0 & 10 & & \\
\hline 81 & Mannino, A. & BIOME & B01 & 45 & 0 & 10 & & \\
\hline 82 & Mannino, A. & BIOME & B02 & 144 & 0 & 10 & & \\
\hline 83 & Mannino, A. & BIOME & B03 & 77 & 0 & 10 & & \\
\hline 84 & Mannino, A. & & B03 Mission Bay & 6 & 0 & 10 & & \\
\hline 85 & Mannino, A. & BIOME & B04 & 126 & 0 & 10 & & \\
\hline 86 & Muller-Karger, F. & CARIACO & car124 & 8 & 0 & 10 & & \\
\hline 87 & Muller-Karger, F. & CARIACO & $\operatorname{car} 125$ & 8 & 0 & 10 & & \\
\hline 88 & Muller-Karger, F. & CARIACO & car126 & 5 & 0 & 10 & & \\
\hline 89 & Muller-Karger, F. & CARIACO & $\operatorname{car} 127$ & 4 & 0 & 10 & & \\
\hline 90 & Muller-Karger, F. & CARIACO & $\operatorname{car} 128$ & 8 & 0 & 10 & & \\
\hline 91 & Muller-Karger, F. & CARIACO & $\operatorname{car} 129$ & 8 & 0 & 10 & & \\
\hline 92 & Muller-Karger, F. & CARIACO & $\operatorname{car} 130$ & 8 & 0 & 10 & & \\
\hline 93 & Mitchell, B. G. & & cce-p0605 & 44 & 0 & 10 & & \\
\hline 94 & Hooker, S. & & en431 & 49 & 0 & 10 & & \\
\hline 95 & Behrenfeld, M. & & gp1-06-ka & 31 & 3.1 & 10 & & \\
\hline 96 & Subramaniam, A. & & jun06atl & 83 & 1.2 & 10 & & \\
\hline 97 & Dierssen, $\mathrm{H}$. & & lisicos0306 & 91 & 0 & 10 & & \\
\hline 98 & Harding, L. & & lmer9304 & 55 & 0 & 10 & & \\
\hline 99 & Harding, L. & & lmer9402 & 53 & 0 & 10 & & \\
\hline 100 & Harding, L. & & lmer9405 & 9 & 0 & 10 & & \\
\hline 101 & Mitchell, G. & & nbp0606 & 123 & 0 & 10 & & \\
\hline 102 & Stumpf, R. & & nc- $03-05$ & 9 & 0 & 10 & & \\
\hline 103 & Stumpf, R. & & nc-04-05 & 2 & 0 & 10 & & \\
\hline 104 & Stumpf, R. & & nc- $06-05$ & 10 & 0 & 10 & & \\
\hline 105 & Stumpf, R. & & nc- $08-05$ & 18 & 5.3 & 10 & & \\
\hline 106 & Mannino, A. & & ODU CBM Transects & 39 & 0 & 10 & & \\
\hline 107 & Dierssen, $\mathrm{H}$. & & ogco06 & 32 & 0 & 10 & & \\
\hline 108 & Nelson, N. & CLIVAR & p16n & 32 & 0 & 10 & & \\
\hline 109 & Harding, L. & & ties 9502 & 39 & 0 & 10 & & \\
\hline 110 & Bidigare, R. and M. Landry & & SOFeX & 112 & 0 & 11 & & \\
\hline 111 & Suzuki, K. & & & 13 & 0 & 2 & & Hayakawa et al. (2008) \\
\hline 112 & Suzuki, K. & & & 102 & 0 & 2 & & Suzuki et al. (2002) \\
\hline 113 & Suzuki, K. & & SEEDS & 35 & 0 & 2 & & Suzuki et al. (2005) \\
\hline 114 & Suzuki, K. & & SEEDS II & 17 & 0 & 2 & & Suzuki et al. (2009) \\
\hline 115 & Wright, S. & & SAZ-SENSE 2006-07 & 381 & 5.5 & 2 & & \\
\hline 116 & Wright, S. & & Broke & 1109 & 0.4 & 2 & & Wright et al. (2010) \\
\hline 117 & Wright, S. & & HIPPIES & 415 & 0 & 2 & & \\
\hline 118 & Wright, S. & & BROKE & 1038 & 5.3 & 2 & & \\
\hline 119 & Smith Jr., W. O. & IVARS & Year 1 & 0 & 85.9 & 2 & & Smith et al. (2006) \\
\hline 120 & Smith Jr., W. O. & IVARS & Year 2 & 50 & 10.5 & 2 & & Smith et al. (2006) \\
\hline
\end{tabular}


Table 1. Continued.

\begin{tabular}{|c|c|c|c|c|c|c|c|c|}
\hline No. & Investigator & Program & Cruise & $N_{\mathrm{QC}}$ & $F_{\text {Rat }}(\%)$ & DS & HPLC method & Data reference \\
\hline 121 & Smith Jr., W. O. & IVARS & Year 3 & 0 & 92.9 & 2 & & Smith et al. (2006) \\
\hline 122 & Smith Jr., W. O. & IVARS & Year 4 & 198 & 26.0 & 2 & & Smith et al. (2006) \\
\hline 123 & Westbrook, G. and D. Robins & AMT Program & Cruise 1 & 104 & 5.4 & 7 & & Aiken et al. (2009) \\
\hline 124 & Gallienne, C. & AMT Program & Cruise 10 & 156 & 5.4 & 7 & & Aiken et al. (2009) \\
\hline 125 & Fernandez, E. & AMT Program & Cruise 11 & 115 & 0 & 7 & & Aiken et al. (2009) \\
\hline 126 & Holligan, P. & AMT Program & Cruise 12 & 223 & 3.5 & 7 & & Aiken et al. (2009) \\
\hline 127 & Holligan, P. & AMT Program & Cruise 13 & 159 & 6.3 & 7 & & Aiken et al. (2009) \\
\hline 128 & Holligan, $\mathrm{P}$. & AMT Program & Cruise 14 & 198 & 3.9 & 7 & & Aiken et al. (2009) \\
\hline 129 & Trees, C. and R. Barlow & AMT Program & Cruise 2 & 78 & 0 & 7 & & Aiken et al. (2009) \\
\hline 130 & Trees, C. and R. Barlow & AMT Program & Cruise 3 & 216 & 2.7 & 7 & & Aiken et al. (2009) \\
\hline 131 & Gibb, S. & AMT Program & Cruise 4 & 268 & 5.2 & 7 & & Gibb et al. (2000) \\
\hline 132 & Gibb, S. & AMT Program & Cruise 5 & 230 & 0.4 & 7 & & Gibb et al. (2000) \\
\hline 133 & Barlow, R. & AMT Program & Cruise 6 & 198 & 0.4 & 7 & & Aiken et al. (2009) \\
\hline 134 & Moore, G. & AMT Program & Cruise 6B & 27 & 10.2 & 7 & & Aiken et al. (2009) \\
\hline 135 & Suggett, D. & AMT Program & Cruise 7 & 243 & 0.3 & 7 & & Aiken et al. (2009) \\
\hline 136 & Holligan, P. & AMT Program & Cruise 8 & 363 & 0.4 & 7 & & Aiken et al. (2009) \\
\hline
\end{tabular}

Data sources: ${ }^{1}$ http://www.obs- vlfr.fr/proof/vt/op/ec/biosope/bio.htm, ${ }^{2}$ Personal communication, ${ }^{3}$ http://globec.whoi.edu/jg/dir/globec/nep/ccs/process/,

${ }^{4}$ http://usjgofs.whoi.edu/jg/dir/jgofs/, ${ }^{5}$ http://hahana.soest.hawaii.edu/hot/ $/{ }^{6}$ http://bats.bios.edu/bats_form_bottle.html, ${ }^{7}$ http://www.bodc.ac.uk/,

${ }^{8} \mathrm{http}: / /$ pal.lternet.edu/data/, ${ }^{9} \mathrm{http}: / / \mathrm{www} . p a n g a e a . d e /,{ }^{10} \mathrm{http}: / /$ seabass.gsfc.nasa.gov/seabasscgi/archive_index.cgi, ${ }^{11} \mathrm{http}: / /$ ocb.whoi.edu/sofex.html,

${ }^{12}$ LOV, H. Claustre and J. Uitz, personal communication, 2008, ${ }^{13} \mathrm{http}: / /$ www.obs-vlfr.fr/cd_rom_dmtt/an_main.htm,

${ }^{14} \mathrm{http} / / /$ www.obs-vlfr.fr/cd_rom_dmtt/eu_main.htm, ${ }^{15} \mathrm{http} / / /$ www.obs-vlfr.fr/cd_rom_dmtt/pr_main.htm, ${ }^{16} \mathrm{http} / / / \mathrm{www}$. obs-vlfr.fr/cd_rom_dmtt/fr_main.htm.

fucoxanthin, lutein, peridinin, prasinoxanthin, violaxanthin and zeaxanthin) in varying proportions within samples, and in varying locations, depths, and months among samples. This suggests the utility of MAREDAT's pigment database for assessing regional, vertical and seasonal scales of phytoplankton community structure and succession.

The following sections describe the data distributions and quality control procedures pertaining to the MAREDAT pigment database. Overall, we intend for the data to be readily exploited by the observational, modeling, and remote sensing communities to deepen understanding of the temporal and spatial diversity of primary producers in the ocean, and the consequences for global carbon fixation.

\section{Methods}

\subsection{HPLC analytical methods}

The majority of the HPLC data in the database were analyzed following standard protocols, with details provided in the original publications (Table 1). The method employed by the Laboratoire d'Océanographie de Villefranche has not been previously described in detail, and is therefore elaborated here.

Generally, 2.8 L of seawater were filtered onto GF/F Whatman $25 \mathrm{~mm}$ filters and frozen until analysis. Prior to 2002, samples were frozen in liquid nitrogen onboard ship, and then at $-20^{\circ} \mathrm{C}$ prior to analysis. After 2002 , samples were frozen at $-80^{\circ} \mathrm{C}$ until analysis. All samples were extracted in $100 \%$ methanol; however, four different analytical protocols (LOV-A, B, C and D) have been applied at the LOV since 1990. Method LOV-A is described in Mantoura and
Llewellyn (1983) with gradient elution as in Williams and Claustre (1991). This reversed-phase C18 method only allowed for a partial resolution of divinyl chlorophyll $a$ (DV $\mathrm{Chl} a$ ) from chlorophyll $a(\mathrm{Chl} a)$. Method LOV-B, based on a reversed phase $\mathrm{C} 8$ column, has been described by Vidussi et al. (1996). It is characterized by complete resolution between DV Chl $a$ and Chl $a$ and partial resolution between zeaxanthin (Zeax) and lutein (Lut). Method LOV-C is a modified version of the Vidussi et al. (1996) method and is described by Claustre et al. (2004). It is characterized by a significant gain in sensitivity. However, inaccuracies with this method arise due to coelution of 19'-hexanoyloxyfucoxanthin (19Hex) and prasinoxanthin (Pras) peaks. Method LOV-D (associated with the BIOSOPE cruise) is a modified version of the $\mathrm{C} 8$ reversed phase Van Heukelem and Thomas (2001) method. It is described by Ras et al. (2008) and is characterized by its capacity for quantifying more than 26 pigments, and for its good resolution of the Zeax/Lut and 19Hex/Pras pairs. Before their submission to MAREDAT, the data underwent quality control procedures including comparison to CTD fluorescence data, detection and elimination of outliers and visual control of each vertical profile.

Since 1999, the LOV analytical procedures have undergone regular unbiased evaluations in the framework of international intercomparison exercises ("round-robins") that comprise NASA's SeaWiFS HPLC Analysis Round-Robin Experiment (SeaHARRE) (see Van Heukelem and Hooker, 2011). SeaHARRE-1 was associated with the PROSOPE project (Hooker et al., 2000), SeaHARRE-2 with the Bencal cruise (Hooker et al., 2005) and SeaHARRE-3 with the 


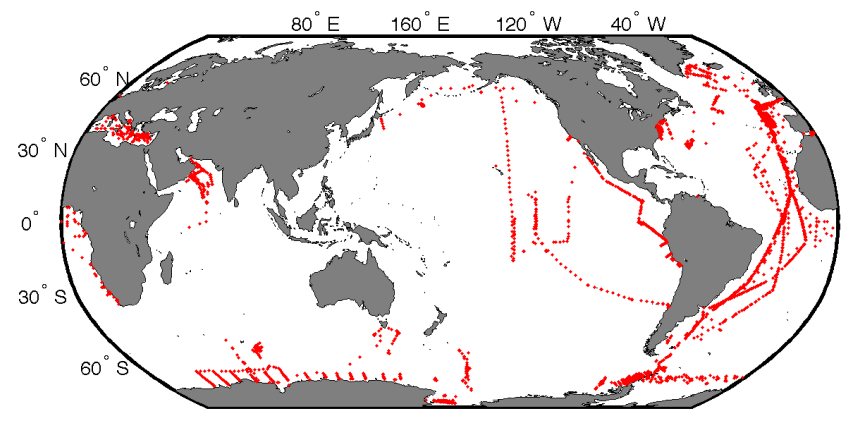

Figure 1. Surface locations of MAREDAT pigment samples that passed quality control (35634 samples).

BIOSOPE project (Hooker et al., 2009). During the roundrobins, the participating laboratories analyzed several series of triplicate samples, resulting in a level of performance associated with each laboratory for a given type of sample. The primary objectives of SeaHARRE were to achieve, with regard to the Sea-viewing Wide Field of View Sensor (SeaWiFS) Project, the pigment accuracy range of $20-25 \%$, with a $15 \%$ range for significant algorithm refinement. Most of the participants have been within the latter range whether in coastal or offshore waters, and the successive SeaHARRE exercises progressively resulted in the improvement of the different methodologies in order to satisfy a number of quality criteria, to reduce uncertainties and to reach optimal performance metrics. Hence, on an international basis, since the LOV-D method was developed for the BIOSOPE cruise, the analytical performance of the LOV has been ranked "state of the art" (Hooker et al., 2005, 2009, 2010). Further, the LOV dataset will be regularly updated in the future with the growing amount of data (see Appendix A1).

\subsection{Quality control for the MAREDAT pigment database}

Marine HPLC measurements from samples taken at various depths and locations around the globe were collected from individual investigators and online data repositories for the individual field campaigns summarized in Table 1. Sampling years spanned from 1989 to 2008 . The full suite of pigments available from each contribution was collected in order to conduct the quality control (QC) analysis. QC procedures followed the protocols of Trees et al. (2000) and Uitz et al. (2006) for data compilations involving contributions from multiple institutes, technicians, and methodologies. A total number of 40536 discrete samples from 136 field surveys were initially compiled for MAREDAT. The geographic locations of the data that passed the full QC analysis are illustrated in Fig. 1.

The first measure of QC flagged samples (" $F_{\mathrm{TC}}$ ”) in which total Chl $a$ concentration (TCHLA; $\mathrm{mg} \mathrm{m}^{-3}$ ) was zero or less $(n=352)$, an indication that pigment concentrations were at or below HPLC instrumental detection limits, and thus not

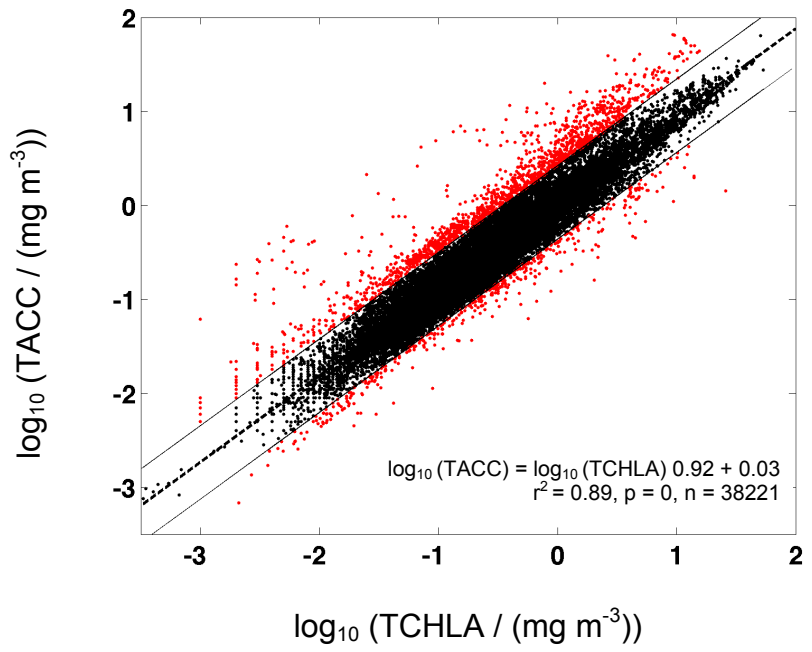

Figure 2. Linear relation between log-normalized total chlorophyll $a$ (TCHLA; $\mathrm{mg} \mathrm{m}^{-3}$ ) and total accessory pigment (TACC; $\left.\mathrm{mg} \mathrm{m}^{-3}\right)$ concentrations. Data $(n=38221)$ are exclusive of samples already flagged for TCHLA values of zero, or for having less than four non-zero accessory pigments. The central dashed line is the fit $\left(\log _{10}\right.$ (TACC) $=\log _{10}$ (TCHLA) $(0.92)+0.03 ; r^{2}=0.89, p=0$, $n=38221$ ). Solid lines represent \pm two standard deviations from the regression, beyond which outlying data points (shown in red) were flagged (" $F_{\text {Rat }}$ ", $n=2001$ ).

resolvable in the sample. TCHLA encompassed all reported $\mathrm{Chl} a$ derivatives, including divinyl chlorophyll $a$, epimers, allomers, and chlorophyllide $a$. The second QC procedure flagged samples (" $F_{\mathrm{TA}}$ ") for which fewer than four non-zero accessory pigments were reported $(n=2306)$, as prior work has indicated that most algal types possess at least four accessory pigments detectable by HPLC (Trees et al., 2000). The third QC measure was based on the log-linear relationship between TCHLA and total accessory pigment concentration (TACC). TACC included photosynthetic carotenoids (19'-butanoyloxyfucoxanthin, 19'-hexanoyloxyfucoxanthin, fucoxanthin, peridinin, prasinoxanthin) and photoprotective carotenoids (alloxanthin, diadinoxanthin, diatoxanthin, lutein, neoxanthin, violaxanthin, zeaxanthin, and carotenes), chlorophylls $b$ and $c$, and phaeopigments. Log transformation was appropriate for the regression as TCHLA varies by over four orders of magnitude globally (Campbell, 1995; Yoder et al., 1993). This QC criterion was built on the observation that phytoplankton maintain a relatively close ratio between their ancillary pigment and total $\mathrm{Chl} a$ concentrations as a consequence of photoacclimation (Trees et al., 2000). The least-squares log-linear fit between TCHLA and TACC $\left(\log _{10}(\right.$ TACC $)=\log _{10}($ TCHLA $)(0.92)+0.03 ; r^{2}=0.89$; $p=0 ; n=38221)$ is displayed with the data in Fig. 2 . The slope of the regression remains remarkably consistent with that observed by Trees et al. (2000) for a smaller subset of global ocean HPLC measurements. 

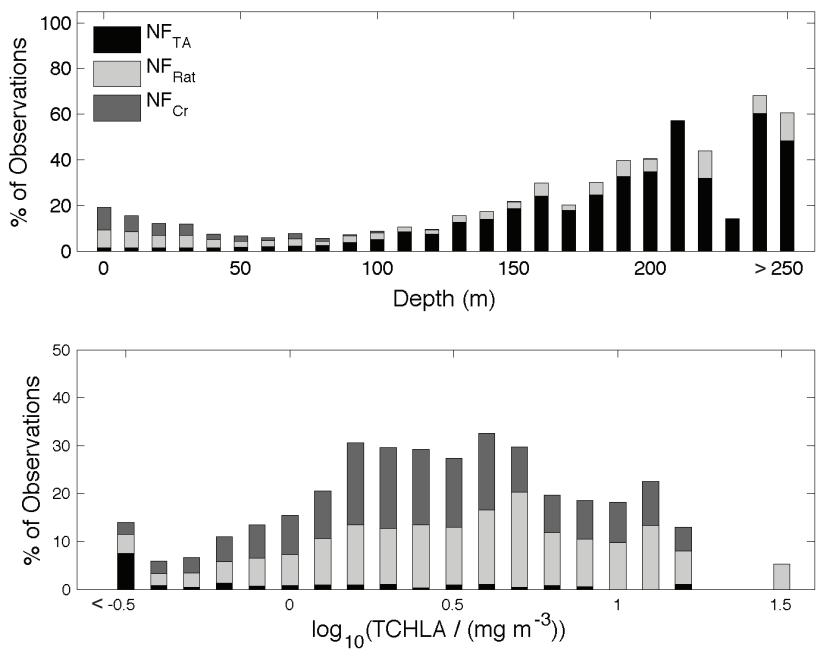

Figure 3. The percent of observations that were flagged due to each quality control measure (exclusive of samples already flagged " $F_{\mathrm{TC}}$ " for TCHLA $\left.\leq 0\right)$ as a function of (a) depth $(\mathrm{m})$ and (b) TCHLA $\left(\mathrm{mg} \mathrm{m}^{-3}\right) . F_{\mathrm{TA}}$ indicates samples flagged for having less than four non-zero accessory pigments; $F_{\text {Rat }}$ indicates regression outliers of the TACC vs. TCHLA relationship; and $F_{\mathrm{Cr}}$ indicates samples for which an entire cruise was flagged due to $35 \%$ or more of the cruise samples acquiring $F_{\text {Rat }}$ flags.

Samples that fell outside the range of two standard deviations of the regression line were flagged (" $F_{\text {Rat }}$ "; $n=$ 2001). The criterion of two standard deviations was chosen to evaluate outlying (i.e., potentially erroneous) measurements without compromising observation of the natural fluctuation about the mean relationship (Uitz et al., 2006). As a final QC criterion, if more than $35 \%$ of samples from a given field campaign (e.g., cruise or time series) was flagged during the third QC step, the entire campaign's samples were flagged (" $F_{\mathrm{Cr}}$ "). This argument was based on the result of applying Chauvenet's criterion (Buitenhuis et al., 2012b) to the cruise percentages of $F_{\text {Rat }}$ flags, which identified 8 outlying cruises, thus flagging an additional 589 samples (Table 1). Overall, 4902 samples were flagged in the QC process, representing $12.1 \%$ of the original collection. The resulting MAREDAT pigment database thus contains 35634 high quality HPLC pigment measurement suites.

There is a clear trend of increased frequency of flagged samples with increased sample depth, mostly driven by the increase in $F_{\mathrm{TA}}$ flags with depth (Fig. 3a). This is consistent with pigment concentrations decreasing to detection limits well below the base of the euphotic zone. The frequency of $F_{\text {Rat }}$, the flag most closely related to HPLC analytical uncertainty (Trees et al., 2000), occurs roughly in proportion to TCHLA, indicating that analytical fidelity is not specifically biased toward low or high chlorophyll levels except within the minimum TCHLA bin (Fig. 3b). a)

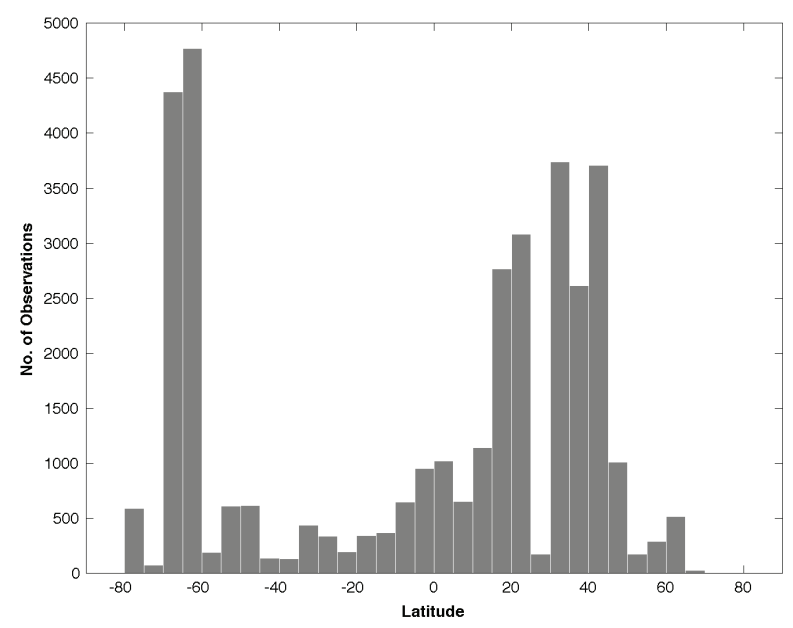

b)

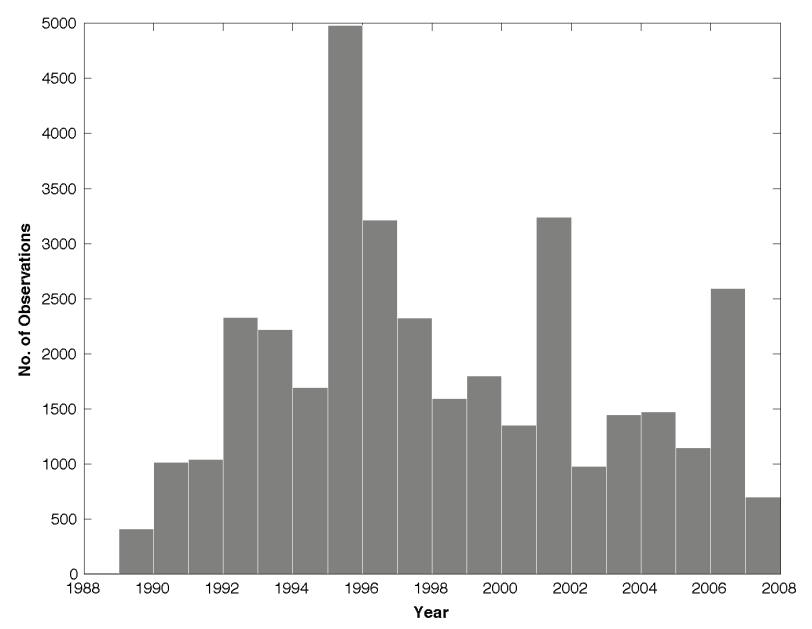

Figure 4. Number of MAREDAT TCHLA observations as a function of (a) latitude and (b) year.

\section{Results}

\subsection{Properties of the quality-controlled MAREDAT pigment database}

The majority of the quality-controlled samples fall within the $0-75 \mathrm{~m}$ depth range, with the upper $20 \mathrm{~m}$ of the water column accounting for $34 \%$ of the dataset. The number of Southern Hemisphere data is biased toward the polar region due to the collectively large contribution of samples from the Palmer Station LTER (Fig. 4a; Table 1). The data distribution for the Southern Hemisphere is also skewed toward the month of January for this reason, as Antarctic waters were typically accessed for HPLC sample collection during austral summer. Samples are overall evenly distributed between the two decades of collection (Fig. 4b). In terms of the seasonal distribution and range in TCHLA values, the MAREDAT pigment database contains good coverage for 
Table 2. Summary of key diagnostic phytoplankton HPLC pigments (adapted from Vidussi et al., 2001): pigment name, common abbreviation, associated taxonomic group and typical size class. For more detailed taxonomic associations and definitions, see Higgins et al. (2011).

\begin{tabular}{lllr}
\hline Pigment & Abbreviation & Taxonomic significance & $\begin{array}{r}\text { Approximate cell } \\
\text { size range }(\mu \mathrm{m})\end{array}$ \\
\hline Zeaxanthin & Zeax & Cyanobacteria and prochlorophytes & $<2$ \\
Divinyl chlorophyll $a$ & DV Chl $a$ & Prochlorococcus spp. & $<2$ \\
Chlorophyll $b$ + Divinyl chlorophyll $b$ & TChl $b$ & Prochlorococcus spp. and green flagellates & $<2$ \\
19 '-hexanoyloxyfucoxanthin & $19 \mathrm{Hex}$ & Chromophytes and nanoflagellates & $2-20$ \\
19 '-butanoyloxyfucoxanthin & $19 \mathrm{But}$ & Chromophytes and nanoflagellates & $2-20$ \\
Alloxanthin & Allox & Cryptophytes & $2-20$ \\
Fucoxanthin & Fuco & Diatoms and haptophytes & $2-20$ \\
Peridinin & Peri & Dinoflagellates (Type 1) & $>20$ \\
\hline
\end{tabular}

both hemispheres. The higher variability in chlorophyll concentration in the Northern Hemisphere than Southern Hemisphere during each season as seen from ocean color observations (Yoder et al., 1993) is also represented by the MAREDAT chlorophyll data (Fig. 5a and b). This relatively lower annual chlorophyll variability in the Southern Hemisphere is due to large areas of Southern Ocean iron depletion limiting the spring phytoplankton blooms (Behrenfeld and Kolber, 1999).

To further assess the quality, range and representation of Chl $a$ measurements in the MAREDAT pigment dataset, we compare TCHLA with remotely sensed chlorophyll. We extracted climatological mean, $9 \mathrm{~km}$-resolution chlorophyll data from NASA's SeaWiFS archive for the years 20002007 (http://oceandata.sci.gsfc.nasa.gov/SeaWiFS/L3SMI/). The extracted chlorophyll data were re-gridded to $1 \times 1^{\circ}$. The mean TCHLA value for the upper $20 \mathrm{~m}$ from the MAREDAT archive (1989-2008) was computed and also re-gridded to $1 \times 1^{\circ}$. The log-transformed SeaWiFS and MAREDAT TCHLA means show generally good agreement $\left(r^{2}=0.5\right.$, $p<0.001, n=1325$; Fig. $6 \mathrm{a}-\mathrm{b})$, given that the predictive capacity of SeaWiFS decreases above $50^{\circ}$ latitude (Yoder et al., 1993). Linear regression of the two properties approximates a $1: 1$ relationship $\left(\log _{10}\right.$ TCHLA SeaWiFS $=-0.29+\log _{10}$ TCHLA MAREDAT 0.97$)$. Higher correlation between MAREDAT and SeaWiFS TCHLA is observed when data from the polar/subpolar latitudes are excluded (i.e., $r^{2}=0.7$ for data within $40^{\circ} \mathrm{S}-40^{\circ} \mathrm{N}$ ), which is consistent with previous comparisons of ocean color and field estimates (Siegel et al., 2005). Furthermore, the median value $\left(0.23 \mathrm{mg} \mathrm{m}^{-3}\right)$ and range in TCHLA (0.001-92.41 $\left.\mathrm{mg} \mathrm{m}^{-3}\right)$ from MAREDAT compare well with the median $\left(0.20 \mathrm{mg} \mathrm{m}^{-3}\right)$ and range (0.01-99.24 $\mathrm{mg} \mathrm{m}^{-3}$ ) in chlorophyll from the SeaWiFS climatology. It must be noted that the SeaWiFS algorithms were likely calibrated with some of the data subsets listed herein. Nonetheless, the substantial number of data considered in this exercise supports the conclusion that there is no significant representation bias of chlorophyll $a$ within MAREDAT. The pigment database covers the global spatiotemporal dy- namics of phytoplankton biomass in the global ocean reasonably well.

\subsection{Distribution of accessory pigments}

The number of samples within the MAREDAT pigment database that contribute to the distribution of each of the accessory pigments is not equal (Fig. 7), as we did not discriminate against contributions without a full suite of accessory pigments. The concentration of chlorophyll $a$ (Fig. 7a) and the key accessory pigments (Fig. 7b-1) generally exhibit a log-normal distribution about their mean. The DV Chl $a$ distribution has the fewest observations (Fig. 7f), potentially because this pigment is not routinely measured during HPLC analysis on high latitude samples.

Figure 8 displays surface concentrations (as the average over the upper $20 \mathrm{~m}$ ) of the main taxonomic pigments from the entire MAREDAT dataset. Figure 9 displays the zonal annual mean depth distributions for the upper $250 \mathrm{~m}$, also using the entire dataset for averaging. Interpretation of the pigment data in terms of phytoplankton taxonomy (e.g., using an inverse method such as CHEMTAX) is beyond the scope of this ESSD paper. It should also be noted that caution must be exercised when using a single pigment distribution as an unambiguous marker for a given algal taxon (Higgins et al., 2011). For example, the distribution of $19 \mathrm{Hex}$, once proposed as relatively indicative of autotrophic flagellates from the nanoplankton size class (Vidussi et al., 2001), is now thought to arise from many phytoplankton sources (Higgins et al., 2011), and is characterized by a rather ubiquitous global distribution (Liu et al., 2009). This conclusion is further supported by the relatively homogenous spatial distribution of 19Hex from MAREDAT (Figs. 8c and 9c).

Recognizing the aforementioned precautions, it is nevertheless interesting to consider the distributions of a few key accessory pigments within MAREDAT that may serve as relative markers for the broader phytoplankton groups given in Table 2 (adapted from Vidussi et al., 2001). For example, DV Chl $a$, which is indicative of the presence of Prochlorococcus spp. (Vidussi et al., 2001), shows highest concentration in 


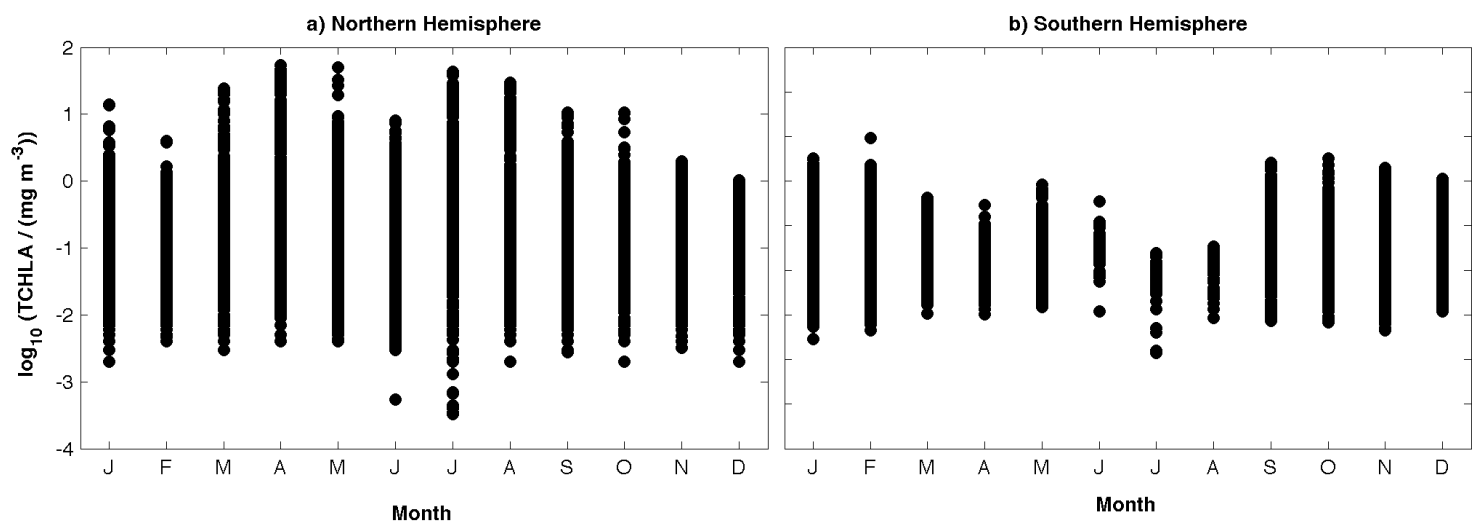

Figure 5. Seasonal distribution of MAREDAT TCHLA values $\left(\mathrm{mg} \mathrm{m}^{-3}\right)$ for the (a) Northern and (b) Southern hemispheres. Data from the equator are included in the Northern Hemisphere panel.
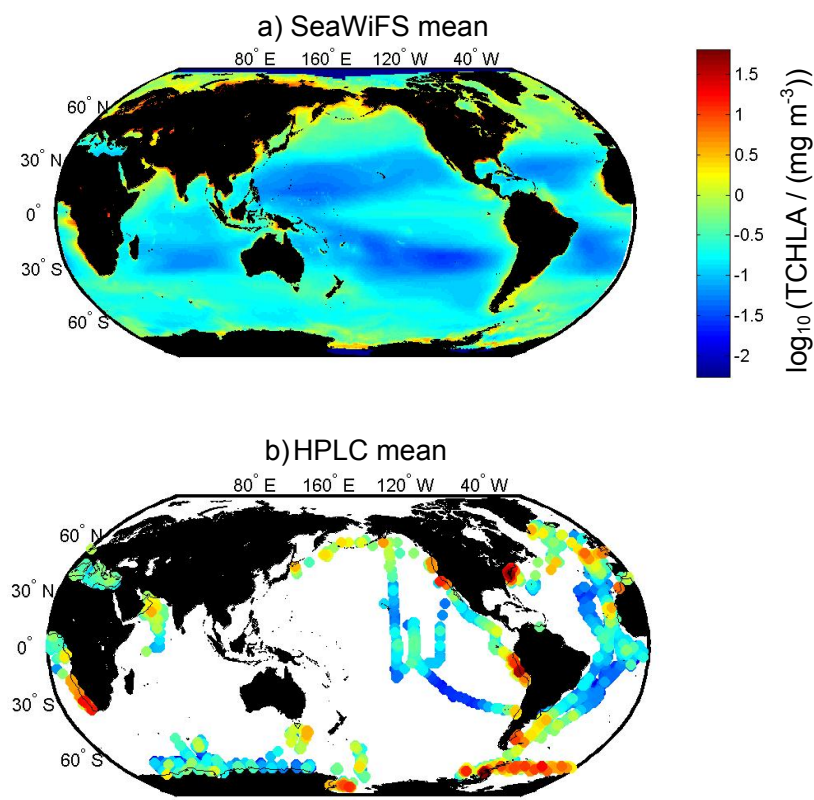

Figure 6. (a) Climatological mean (2000-2007) chlorophyll $a$ concentration $\left(\mathrm{mg} \mathrm{m}^{-3}\right)$ from SeaWiFS (scaled to $1^{\circ}$ resolution) and (b) surface TCHLA $\left(\mathrm{mg} \mathrm{m}^{-3}\right)$ from MAREDAT (averaged over the upper $20 \mathrm{~m}$ and scaled to $1^{\circ}$ resolution.)

the tropical regions of the eastern Pacific and Indian oceans (Figs. 8f and 9f). This finding is consistent with prior reports on Prochlorococcus spp. distributions based on cell counts (Goericke et al., 2000; Buitenhuis et al., 2012a). Similarly, fucoxanthin (Fuco) is widely considered to be diagnostic of diatoms in regions where diatoms dominate the autotrophic abundance (e.g., high latitude productive areas; Wright et al., 2010), and accordingly the MAREDAT data show a bias for Fuco toward polar regions (Figs. 8g and 9g, respectively). Finally, the MAREDAT pigment dataset shows that Zeax is relatively confined to the warm tropical and subtropical wa- ters of each basin (Figs. 81 and 91). Zeax roughly marks the presence of cyanobacteria, which are recognized dominants in these lower latitude regions (Claustre and Marty, 1995; Vidussi et al., 2001; see also global biomass assessment of Synechococcus and Prochlorococcus spp. in Buitenhuis et al., 2012a).

\section{Recommendations for use}

The quality-controlled MAREDAT pigment database may be exploited using any number of approaches to estimate phytoplankton community structure in the global ocean. Some of these approaches include the diagnostic pigment method to determine size fractions (Vidussi et al., 2001; Uitz et al., 2006), least-squares solutions (Letelier et al., 1993; Andersen et al., 1996), CHEMTAX analysis (Mackey et al., 1996) and similar approaches (Goericke and Montoya, 1998; van den Meersche et al., 2008). Regardless of method, care must always be taken to ensure that the regional or global algorithms applied are appropriate for the temporal or spatial scale in question. Furthermore, results should be validated with independent measures of assemblage composition (e.g., flow cell counts, microscopy) when possible. New global MAREDAT compilations of phytoplankton species abundance and biomass data from microscopic and cell counting methods (see this special issue) will aid in mapping discrete populations sampled by the pigment database for an effective global chemotaxonomic analysis. The presence/absence species information from MAREDAT, for example, may better inform accurate selection of "seed" pigment ratios that are needed for achieving robust quantitative results from CHEMTAX (Mackey et al., 1996; Wright et al., 2010). In contrast, abundance-based biomass data from MAREDAT may allow for quantitative comparison with the CHEMTAX results (e.g., Llewellyn et al., 2005). Future assessments will benefit greatly from updated summaries on plankton pigment ratios (Higgins et al., 2011). 

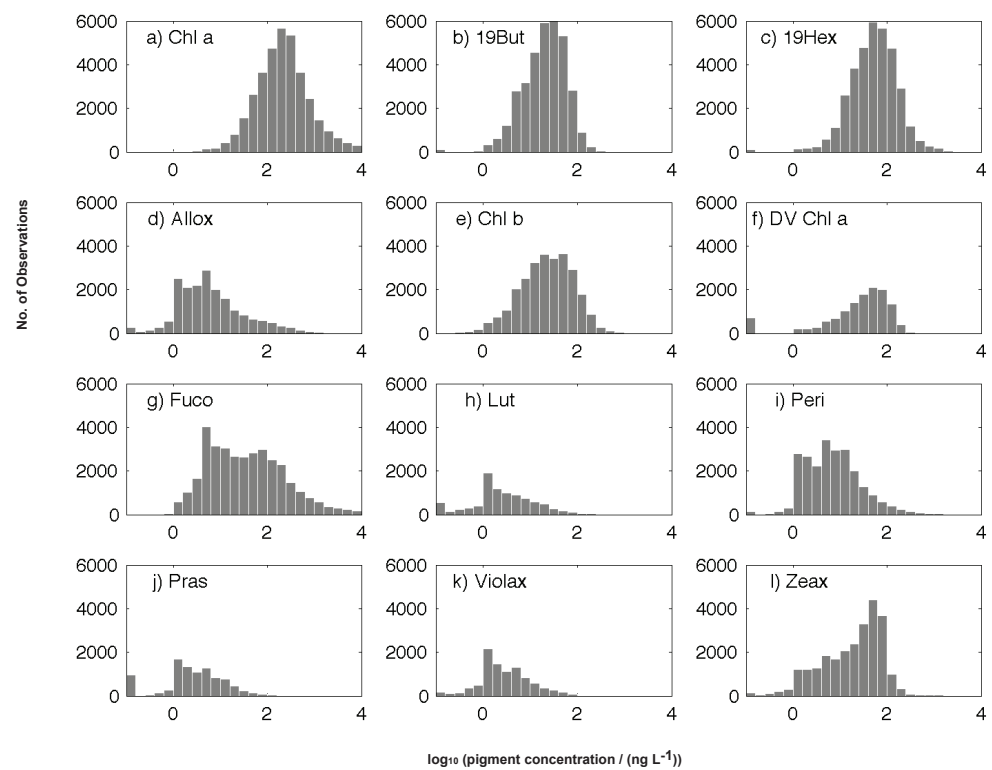

Figure 7. Number of MAREDAT pigment observations as a function of concentration (ng L $\left.{ }^{-1}\right)$ : (a) chlorophyll $a$ (Chl $a$ ), (b) 19 'butanoyloxyfucoxanthin (19But), (c) 19'-hexanoyloxyfucoxanthin (19Hex), (d) alloxanthin (Allox), (e) chlorophyll $b$ (Chl $b$ ), (f) divinyl chlorophyll $a$ (DV Chl $a$ ), (g) fucoxanthin (Fuco), (h) lutein (Lut), (i) peridinin (Peri), (j) prasinoxanthin (Pras), (k) violaxanthin (Violax) and (l) zeaxanthin (Zeax).
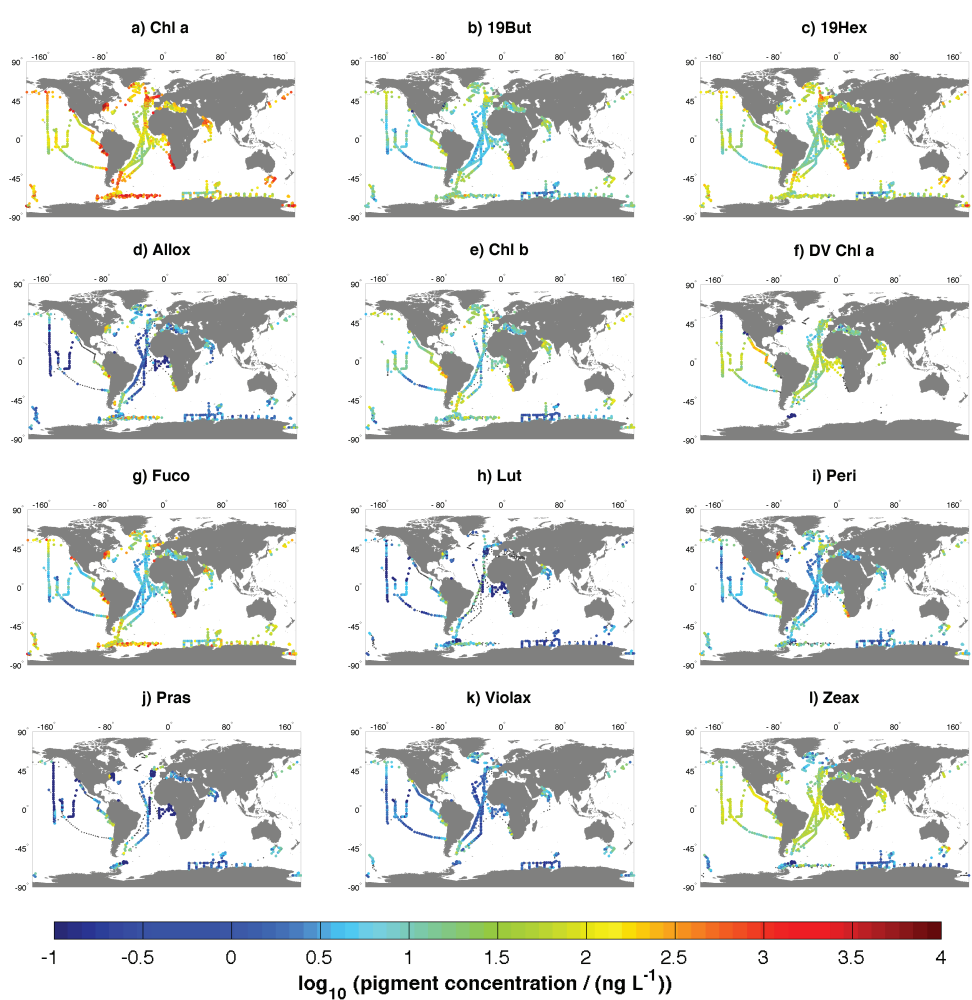

Figure 8. Pigment concentrations (ng $\mathrm{L}^{-1}$ ) from MAREDAT averaged over the upper 20 m: (a) chlorophyll $a$ (Chl $a$ ), (b) 19'butanoyloxyfucoxanthin (19But), (c) 19'-hexanoyloxyfucoxanthin (19Hex), (d) alloxanthin (Allox), (e) chlorophyll $b$ (Chl $b$ ), (f) divinyl chlorophyll $a$ (DV Chl $a$ ), (g) fucoxanthin (Fuco), (h) lutein (Lut), (i) peridinin (Peri), (j) prasinoxanthin (Pras), (k) violaxanthin (Violax) and (l) zeaxanthin (Zeax). Data from all years were used in the averaging. 

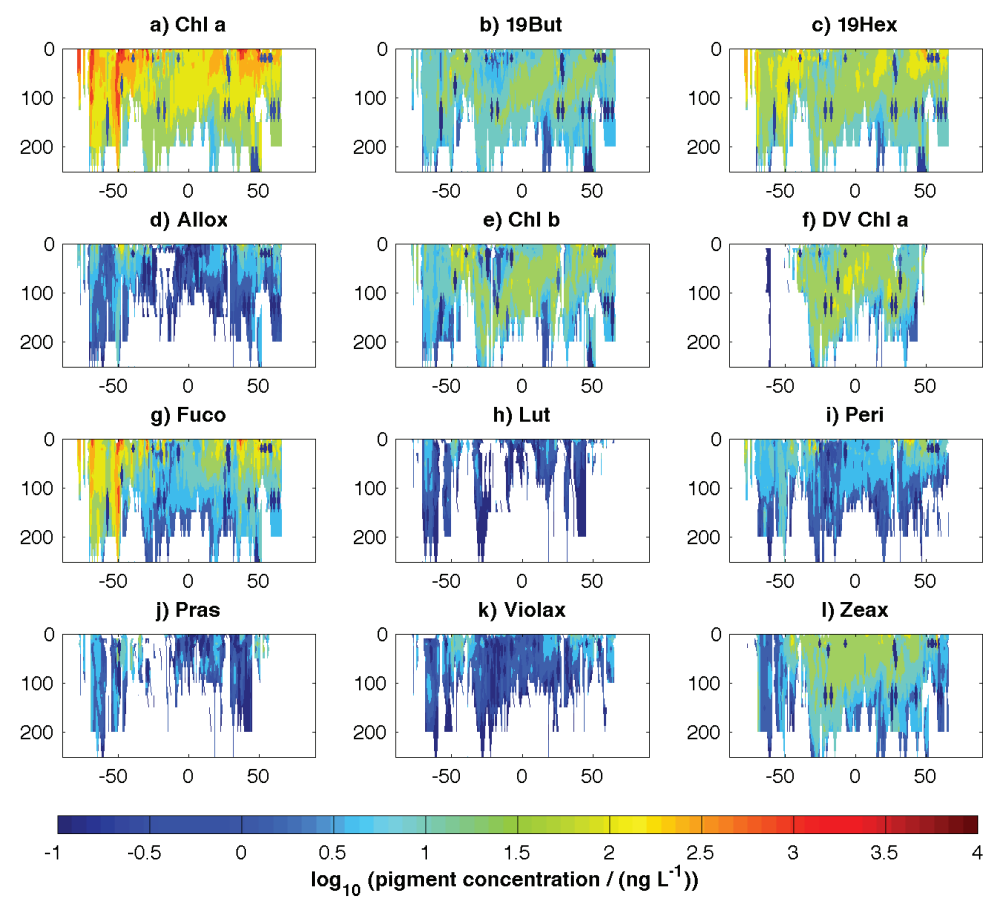

Figure 9. Zonal annual mean depth profiles of MAREDAT pigment concentrations (ng L ${ }^{-1}$ ) as a function of latitude: (a) chlorophyll $a$ (Chl $a$ ), (b) 19'-butanoyloxyfucoxanthin (19But), (c) 19'-hexanoyloxyfucoxanthin (19Hex), (d) alloxanthin (Allox), (e) chlorophyll $b$ (Chl $b$ ), (f) divinyl chlorophyll $a$ (DV Chl $a$ ), (g) fucoxanthin (Fuco), (h) lutein (Lut), (i) peridinin (Peri), (j) prasinoxanthin (Pras), (k) violaxanthin (Violax) and (l) zeaxanthin (Zeax). The gridded data product (see Appendix A2: netCDF product) was used to compute the zonal and the annual mean (from $1^{\circ}$ monthly mean climatologies).

Ideal applications for chemotaxonomic workup results of the MAREDAT data are to (a) better ground-truth satellite estimates of phytoplankton functional types or size fractions, (b) determine biological niches in the ocean from phytoplankton community structure, and (c) evaluate MAREDATbased results against output from ecosystem models that translate physiological observations into phytoplankton community distributions. While climatological mean $\mathrm{Chl} a$ signals from both MAREDAT and SeaWiFS are in good agreement, chlorophyll and accessory pigment concentrations in a given region vary widely in time, especially in areas with large seasonality in phytoplankton composition (Yoder et al., 1993). Thus, if results from MAREDAT pigment analysis are to be used for model comparisons, a point-to-point evaluation by month is recommended.

The MAREDAT pigment database is viewed as a living dataset, with the expectation of new HPLC data contributions and improvements in the future. We anticipate that new product-specific datasets, such as those forming the MAREDAT initiative, will permit exciting synergies and scientific gains across several disciplines.

\section{Appendix A}

\section{A1 Data table}

A full data table containing all pigment suites can be downloaded from the data archive PANGAEA: http://doi.pangaea. de/10.1594/PANGAEA.793246. The data file contains longitude, latitude, depth, sampling date and time, total chlorophyll $a$ and total accessory pigment concentrations, the individual pigment concentrations, all quality flags, as well as the full data references. As a subset, a distinct archive reference is dedicated to the dataset originating from the LOV: http://doi.pangaea.de/10.1594/PANGAEA.808535.

\section{A2 Gridded netCDF product}

HPLC-derived pigment concentrations (chlorophyll $a$, 19'butanoyloxyfucoxanthin, 19'-hexanoyloxyfucoxanthin, alloxanthin, chlorophyll $b$, divinyl chlorophyll $a$, fucoxanthin, lutein, peridinin, prasinoxanthin, violaxanthin, and zeaxanthin) have been gridded onto a $360 \times 180^{\circ}$ grid, with a vertical resolution of 33 depth levels (equivalent to World Ocean Atlas depths) and a temporal resolution of 12 months (climatological monthly means). Data has been converted to netCDF format for easy use in model evaluation exercises. The 
netCDF file can also be downloaded at http://doi.pangaea. de/10.1594/PANGAEA.793246.

Acknowledgements. J. Peloquin, C. Swan, N. Gruber and M. Vogt were funded by ETH Zürich. C. O'Brien has received funding from the European Community's Seventh Framework Programme (FP7 2007-2013) under grant agreement no. 238366. We are grateful to two anonymous reviewers for their evaluation of this manuscript. We thank Erik Buitenhuis for producing the gridded netCDF product, Stephane Pesant for archiving the data on www.Pangaea.de, and Dave Carlson and Hans Pfeiffenberger at ESSD for their patience. We would like to further acknowledge Gerald Moore, Denise Cummings, Tony Knap, Dave Robins, Dave Suggett and Guy Westbrook for their HPLC data contributions. We are equally grateful for all the project PIs who contributed data, as well as for the anonymous staff who took part in the sampling work during the cruises, who carried out the HPLC analysis, and without whom the construction of such a database would not have been possible. Most of the data from the LOV database were acquired as part of the French national programs JGOFS-France, PROOF and CYBER, which were funded by CNRS-INSU.

Edited by: S. Pesant

\section{References}

Aiken, J., Pradhan, Y., Barlow, R., Lavender, S., Poulton, A., Holligan, P., and Hardman-Mountford, N.: Phytoplankton pigments and functional types in the Atlantic Ocean: A decadal assessment, 1995-2005. Deep-Sea Res. Pt. II, 56, 899-917, 2009.

Alvain, S., Moulin, C., Dandonneau, Y., and Bréon, F.: Remote sensing of phytoplankton groups in case I waters from global SeaWiFS imagery, Deep-Sea Res. Pt. I, 52, 1989-2004, 2005.

Alvain, S., Moulin, C., Dandonneau, Y., and Loisel, H.: Seasonal distribution and succession of dominant phytoplankton groups in the global ocean: A satellite view, Global Biogeochem. Cy., 22, GB3001, doi:10.1029/2007GB003154, 2008.

Andersen, R., Bidigare, R., Keller, M., and Latasa, M.: A comparison of HPLC signatures and electron microscopic observations for oligotrophic waters of the North Atlantic and Pacific Oceans, Deep-Sea Res., 43, 517-537, 1996.

Anderson, T. R.: Plankton functional type modelling: running before we can walk?, J. Plankton Res., 27, 1073-1081, doi:10.1093/plankt/fbi076, 2005.

Behrenfeld, M. J. and Kolber, Z. S.: Widespread iron limitation of phytoplankton in the South Pacific ocean, Science, 283, 840843, 1999.

Bidigare, R.: "HPLC Pigments." Ocean Carbon and Biogeochemistry Data System, OCB DMO, WHOI, iPub: 19 May 1999, http://usjgofs.whoi.edu/jg/dir/jgofs/southern/nbp96_4A/, last access: July 2010a.

Bidigare, R.: "HPLC Pigments." Ocean Carbon and Biogeochemistry Data System, OCB DMO, WHOI, iPub: 19 May 1999, http://usjgofs.whoi.edu/jg/dir/jgofs/southern/nbp97_1/, last access: July 2010 b.

Bidigare, R.: "HPLC Pigments." Ocean Carbon and Biogeochemistry Data System, OCB DMO, WHOI, iPub: 20 May 1999, http://usjgofs.whoi.edu/jg/dir/jgofs/southern/nbp97_3/, last access: July 2010c.

Bidigare, R.: "HPLC Pigments." Ocean Carbon and Biogeochemistry Data System, OCB DMO, WHOI, iPub: 20 March 1999, http://usjgofs.whoi.edu/jg/dir/jgofs/southern/nbp97_8/, last access: July 2010d.

Bidigare, R.: "HPLC Pigments and HPLC PigmentsTM.", Ocean Carbon and Biogeochemistry Data System, OCB DMO, WHOI, iPub: 8 May 2001, http://usjgofs.whoi.edu/jg/dir/jgofs/arabian/ ttn-045/, last access: July 2010e.

Bidigare, R.: "HPLC Pigments and HPLC PigmentsPP.” Ocean Carbon and Biogeochemistry Data System, OCB DMO, WHOI, iPub: 8 May 2001, http://usjgofs.whoi.edu/jg/dir/jgofs/arabian/ ttn-050/, last access: July 2010f.

Bidigare, R.: "HPLC Pigments." Ocean Carbon and Biogeochemistry Data System, OCB DMO, WHOI, iPub: 8 May 2001, http: //usjgofs.whoi.edu/jg/dir/jgofs/arabian/ttn-053/, last access: July $2010 \mathrm{~g}$.

Bidigare, R.: "Pigments.” Ocean Carbon and Biogeochemistry Data System, OCB DMO, WHOI, iPub: 24 April 1995, http://usjgofs. whoi.edu/jg/dir/jgofs/eqpac/tt007/, last access: July 2010h.

Bidigare, R.: "Pigments." Ocean Carbon and Biogeochemistry Data System, OCB DMO, WHOI, iPub: 24 June 2002, http://usjgofs whoi.edu/jg/dir/jgofs/eqpac/tt008/, last access: July 2010 i.

Bidigare, R.: "Pigments." Ocean Carbon and Biogeochemistry Data System, OCB DMO, WHOI, iPub: 24 June 2002, http://usjgofs. whoi.edu/jg/dir/jgofs/eqpac/tt11/, last access: July 2010j.

Bidigare, R.: "Pigments." Ocean Carbon and Biogeochemistry Data System, OCB DMO, WHOI, iPub: 24 June 2002, http://usjgofs. whoi.edu/jg/dir/jgofs/eqpac/tt12/, last access: July 2010k.

Brewin, R., Lavendar, S., Hardman-Mountford, N., and Hirata, T.: A spectral response approach for detecting dominant phytoplankton size class from satellite remote sensing, Acta Oceanol. Sin., 29, 14-32, 2010.

Buitenhuis, E. T., Li, W. K. W., Vaulot, D., Lomas, M. W., Landry, M. R., Partensky, F., Karl, D. M., Ulloa, O., Campbell, L., Jacquet, S., Lantoine, F., Chavez, F., Macias, D., Gosselin, M., and McManus, G. B.: Picophytoplankton biomass distribution in the global ocean, Earth Syst. Sci. Data, 4, 37-46, doi:10.5194/essd-4-37-2012, 2012a.

Buitenhuis, E. T., Vogt, M., Moriarty, R., Bednaršek, N., Doney, S. C., Leblanc, K., Le Quéré, C., Luo, Y.-W., O’Brien, C., O’Brien, T., Peloquin, J., Schiebel, R., and Swan, C.: MAREDAT: towards a World Ocean Atlas of MARine Ecosystem DATa, Earth Syst. Sci. Data Discuss., 5, 1077-1106, doi:10.5194/essdd-51077-2012, 2012b.

Campbell, J.: The lognormal distribution as a model for bio-optical variability in the sea, J. Geophys. Res., 100, 13237-13254, 1995.

Ciotti, A. and Bricaud, A.: Retrievals of a size parameter for phytoplankton and spectral light absorption by coloured detrital matter from water-leaving radiances at SeaWiFS channels in a continental shelf off Brazil, Limnol. Oceanogr.-Meth., 4, 237-253, 2006.

Claustre, H.: Phytoplankton pigment signatures of the trophic status in various oceanic regimes, Limnol. Oceanogr., 39, 1206-1211, 1994.

Claustre, H. and Marty, J.-C.: Specific phytoplankton biomasses and their relation to primary production in the tropical North Atlantic, Deep-Sea Res., 42, 1475-1493, 1995. 
Claustre, H., Kerhervé, P., Marty, J.-C., and Prieur, L.: Phytoplankton photoadaptation in relation to some frontal physical processes, J. Marine Syst., 5, 251-265, 1994a.

Claustre, H., Kerhervé, P., Marty, J.-C., Prieur, L., Videau, C., and Hecq, J.: Phytoplankton distribution associated with a geostrophic front : ecological and biogeochemical implications, J. Mar. Res., 52, 711-742, 1994b.

Claustre, H., Hooker, S., Van Heukelem, L., Berthond, J.-F., Barlowe, R., Ras, J., Sessions, H., Targa, C., Thomas, C., van der Linded, D., and Marty, J.-C.: An intercomparison of HPLC phytoplankton pigment methods using in situ samples: application to remote sensing and database activities, Mar. Chem., 85, 41-61, 2004

Claustre, H., Babin, M., Merien, D., Ras, J., Prieur, L., Dallot, S., Prasil, O., Dousova, H., and Moutin, T.: Towards a taxon-specific parameterization of bio-optical models of primary production: a case study in the North Atlantic, J. Geophys. Res., 110, C07S12, doi:10.1029/2004JC002634, 2005.

Demarcq, H., Reygondeau, G., Alvain, S., and Vantrepotte, V.: Monitoring marine phytoplankton seasonality from space, Remote. Sens. Environ., 117, 211-222, 2012.

DiTullio, G., Geesey, M., Maucher, J., Alm, M., Riseman, S., and Bruland, K.: Influence of iron on algal community composition and physiological status in the Peru upwelling system, Limnol. Oceanogr., 50, 1887-1907, 2005.

Doney, S., Lima, I., Moore, J., Lindsay, K., Behrenfeld, M., Westberry, T., Mahowald, N., Glover, D., and Takahashi, T.: Skill metrics for confronting global upper ocean ecosystembiogeochemistry models against field and remote sensing data, J. Marine Syst., 76, 950-112, 2009.

Gibb, S. Barlow, R., Cummings, D., Rees, N., Trees, C., Holligan, P., and Suggett, D.: Surface phytoplankton pigment distributions in the Atlantic Ocean: an assessment of basin scale variability between $50^{\circ} \mathrm{N}$ and $50^{\circ} \mathrm{S}$, Prog. Oceanogr., 45, 339-368, doi:10.1016/S0079-6611(00)00007-0, 2000.

Goericke, R.: "HPLC Pigments." Ocean Carbon and Biogeochemistry Data System, OCB DMO, WHOI, iPub: 14 September 2001, http://usjgofs.whoi.edu/jg/dir/jgofs/southern/rr-kiwi_ 6/, last access: July 2010a.

Goericke, R.: "HPLC Pigments." Ocean Carbon and Biogeochemistry Data System, OCB DMO, WHOI, iPub: 19 May 1999, http://usjgofs.whoi.edu/jg/dir/jgofs/southern/rr-kiwi_7/, last access: July 2010 b.

Goericke, R.: "HPLC Pigments." Ocean Carbon and Biogeochemistry Data System, OCB DMO, WHOI, iPub: 19 May 1999, http://usjgofs.whoi.edu/jg/dir/jgofs/southern/rr-kiwi_8/, last access: July 2010c.

Goericke, R.: "HPLC Pigments." Ocean Carbon and Biogeochemistry Data System, OCB DMO, WHOI, iPub: 24 August 2001, http://usjgofs.whoi.edu/jg/dir/jgofs/southern/rr-kiwi_8/, last access: July 2010d.

Goericke, R.: "HPLC Pigments." Ocean Carbon and Biogeochemistry Data System, OCB DMO, WHOI, iPub: 9 April 2002, http://usjgofs.whoi.edu/jg/dir/jgofs/arabian/ttn-043/, last access: July 2010e.

Goericke, R.: "HPLC Pigments." Ocean Carbon and Biogeochemistry Data System, OCB DMO, WHOI, iPub: 9 April 2002, http://usjgofs.whoi.edu/jg/dir/jgofs/arabian/ttn-049/, last access: July $2010 f$.
Goericke, R.: "HPLC Pigments." Ocean Carbon and Biogeochemistry Data System, OCB DMO, WHOI, iPub: 23 August 2001, http://usjgofs.whoi.edu/jg/dir/jgofs/arabian/ttn-054/, last access: July $2010 \mathrm{~g}$.

Goericke, R. and Montoya, J.: Estimating the contribution of microalgal taxa to chlorophyll a in the field - variations of pigment ratios under nutrient- and light-limited growth, Mar. Ecol.-Prog. Ser., 169, 97-112, 1998.

Goericke, R., Olson, R. J., and Shalapyonok, A.: A novel niche for Prochlorococcus sp. in low-light suboxic environments in the Arabian Sea and the Eastern Tropical North Pacific, Deep-Sea Res. Pt. I, 47, 1183-1205, 2000.

Havskum, H., Schluter, L., Scharek, R., Berdalet, E., and Jacquet, S.: Routine quantification of phytoplankton groups - microscopy or pigment analyses?, Mar. Ecol.-Prog. Ser., 273, 31-42, 2004.

Hayakawa, M., Suzuki, K., Saito, H., Takahashi, K., and Ito, S.: Differences in cell viabilities of phytoplankton between spring and late summer in the northwest Pacific Ocean, Exp. Mar. Biol. Ecol., 360, 63-70, 2008.

Head, E.: , 2002.

Higgins, H., Wright, S., and Schluter, L.: Quantitative interpretation of chemotaxonomic pigment data, in: Phytoplankton Pigments: Characterization, Chemotaxonomy and Applications in Oceanography, edited by: Roy, S., Llewellyn, C., Egeland, E., and Johnsen, G., Cambridge University Press, 2011.

Hirata, T., Aiken, J., Hardman-Mountford, N., Smyth, T., and Barlow, R.: An absorption model to determine phytoplankton size classes from satellite ocean colour, Remote Sens. Environ., 112, 3153-3159, 2008.

Hirata, T., Hardman-Mountford, N. J., Brewin, R. J. W., Aiken, J., Barlow, R., Suzuki, K., Isada, T., Howell, E., Hashioka, T., Noguchi-Aita, M., and Yamanaka, Y.: Synoptic relationships between surface Chlorophyll- $a$ and diagnostic pigments specific to phytoplankton functional types, Biogeosciences, 8, 311-327, doi:10.5194/bg-8-311-2011, 2011.

Hood, R., Laws, E., Armstrong, R., Bates, N., Brown, C., Carlson, C. A., Chai, F., Doney, S. C., Falkowski, P. G., Feely, R. A., Friedrichs, M. A. M., Landry, M. R., Moore, J. K., Nelson, D. M., Richardson, T. L., Salihoglu, B., Schartau, M., Toole, D. A., and Wiggert, J. D.: Pelagic functional group modeling: progress, challenges and prospects, Deep-Sea Res. Pt. II, 53, 459-512, 2006.

Hooker, S. B., Claustre, H., Ras, J., Van Heukelem, L., Berthon, J.-F., Targa, C., van der Linde, D., Barlow, R., and Sessions, H.: The First SeaWiFS HPLC Analysis Round-Robin Experiment (SeaHARRE-1), NASA Tech. Memo. 2000-206892, Vol. 14, edited by: Hooker, S. B. and Firestone, E. R., NASA Goddard Space Flight Center, Greenbelt, Maryland, 42 pp., 2000.

Hooker, S. B., Van Heukelem, L., Thomas, C. S., Claustre, H., Ras, J., Barlow, R., Sessions, H., Schluter, L., Perl, J., Trees, C., Stuart, V., Head, E., Clementson, L., Fishwick, J., Llewellyn, C. A., and Aiken, J.: The second SeaWiFS HPLC analysis round-robin experiment (SeaHAARE-2), NASA, Goddard Space Flight Center, NASA/TM-2005-212787, 112 pp., 2005.

Hooker, S. B., Van Heukelem, L., Thomas, C. S., Claustre, H., Ras, J., Schluter, L., Clementson, L, van der Linde, D., EkerDeveli, E., Berthon, J.-F., Barlow, R., Sessions, H., Ismail, H., and Perl, J.: The third SeaWiFS HPLC analysis round-robin experiment (SeaHAARE-3), NASA, Calibration and Validation Of- 
fice, NASA/TM-2009-215849, 97 pp., 2009.

Hooker, S. B., Thomas, C. S., Van Heukelem, L., Schluter, L., Russ, M. E., Ras, J., Claustre, H., Clementson, L., Canuti, E., Berthon, J.-F., Perl, J., Normandeau, C., Cullen, J. J., Kienast, M., and Pinckney, J. L.: The fourth SeaWiFS HPLC analysis round-robin experiment (SeaHAARE-4), NASA, Calibration and Validation Office, NASA/TM-2010-215857, 74 pp., 2010.

Kostadinov, T., Siegel, D., and Maritorena, S.: Retrieval of the particle size distribution from satellite ocean color observations, J. Geophys. Res., 114, C09015, doi:10.1029/2009JC005303, 2009.

Kozlowski, W. A., Deutschman, D., Garibotti, I., Trees, C., and Vernet, M.: An evaluation of the application of CHEMTAX to Antarctic coastal pigment data, Deep-Sea Res. I, 58, 350-364, 2011.

Le Quéré, C., Harrison, S., Prentice, C., Buitenhuis, E. T., Aumont, O., Bopp, L., Claustre, H., Cotrim da Cunha, L., Geider, R., Giraud, X., Klaas, C., Kohfeld, K. E., Legendre, L., Manizza, M., Platt, T., Rivkin, R., Sathyendranath, S., Uitz, J., Watson, A. J., and Wolf-Gladrow, D.: Ecosystem dynamics based on plankton functional types for global ocean biogeochemistry models, Glob. Change Biol., 11, 2016-2040, 2005.

Letelier, R.: "Phytoplankton." Ocean Carbon and Biogeochemistry Data System, OCB DMO, WHOI, iPub: nd, http://globec.whoi. edu/jg/dir/globec/nep/ccs/process/, last access: August 2007.

Letelier, R., Bidigare, R., Hebel, D., Ondrusek, M., Winn, C., and Karl, D.: Temporal variability of phytoplankton community structure based on pigment analysis, Limnol. Oceanogr., 38, 1420-1437, 1993.

Llewellyn, C., Fishwick, J., and Blackford, J.: Phytoplankton community assemblage in the English Channel: a comparison using chlorophyll a derived from HPLC-CHEMTAX and carbon derived from microscopy cell counts, J. Plankton Res., 27, 103119, 2005

Li, W. and Wood, A.: Vertical distribution of North Atlantic ultraphytoplankton: analysis by flow cytometry and epifluorescence microscopy, Deep-Sea Res., 35, 1615-1638, 1988.

Liu, H., Probert, I., Uitz, J., Claustre, H., Aris-Brosou, S., Frada, M., Not, F., and de Vargas, C.: Haptophyta rule the waves: Extreme oceanic biodiversity in non-calcifying prymnesiophytes explains the 19-Hex paradox, P. Natl. Acad. Sci., 106, 1280312808, doi:10.1073/pnas.0905841106, 2009.

Lowry, R.: BODC: doi:10.1594/PANGAEA.198134, 198151, 198417, 198419, 2004.

Mackey, M., Mackey, D., Higgins, H., and Wright, S.: CHEM$\mathrm{TAX}$ - a program for estimating class abundances from chemical markers: application to HPLC measurements of phytoplankton, Mar. Ecol.-Prog. Ser., 144, 265-283, 1996.

Mantoura, R. F. C. and Llewellyn, C. A.: The rapid determination of algal chlorophyll and carotenoid pigments and their breakdown products in natural waters by reverse-phase high-performance liquid chromatography, Anal. Chim. Acta, 151, 293-314, 1983.

Marty, J.-C.: doi:10.1594/PANGAEA.136858, 2004.

Marty, J.-C., Chiaverini J., Pizay, M. D., and Avril, B.: Seasonal and interannual dynamics of nutrients and phytoplankton pigments in the western Mediterranean Sea at the DYFAMED time-series station (1991-1999), Deep-Sea Res. Pt. II, 49, 1965-1985, 2002.

Morel, A., Gentili, B., Chami, M., and Ras, J.: Bio-optical properties of high chlorophyll Case 1 waters, and of yellow-substancedominated Case 2 waters, Deep-Sea Res. Pt. I, 53, 1439-1559,
2006.

Raitsos, D., Lavendar, S., Maravelias, C., Haralabous, J., Richardson, A., and Reid, P.: Identifying four phytoplankton functional types from space: An ecological approach, Limonol. Oceanogr., 53, 605-613, 2008.

Ras, J., Claustre, H., and Uitz, J.: Spatial variability of phytoplankton pigment distributions in the Subtropical South Pacific Ocean: comparison between in situ and predicted data, Biogeosciences, 5, 353-369, doi:10.5194/bg-5-353-2008, 2008.

Repeta, D.: "Pigments." Ocean Carbon and Biogeochemistry Data System, OCB DMO, WHOI, iPub: 14 January 2003, http: //usjgofs.whoi.edu/jg/dir/jgofs/nabe/atlantisII/, last access: July 2010.

Siegel, D. A., Maritorena, S., Nelson, N. B., and Behrenfeld, M. J.: Independence and interdependencies of global ocean color properties: reassessing the bio-optical assumption, J. Geophys. Res., 110, C07011, doi:10.1029/2004JC002527, 2005.

Smith Jr., W. O., Shields, A., Peloquin, J., Catalano, G., Tozzi, S., Dinniman, M., and Asper, V.: Interannual variations in nutrients, net community production, and biogeochemical cycles in the Ross Sea, Deep-Sea Res. Pt. II, 53, 815-833, 2006.

Suzuki, K., Minami, C., Liu, H., and Saino, T.: Temporal and spatial patterns of chemotaxonomic algal pigments in the subarctic Pacific and the Bering Sea during the early summer of 1999, Deep-Sea Res. Pt. II, 49, 5685-5704, 2002.

Suzuki, K., Hinuma, A., Saito, H., Kiyosawa, H., Liu, H., Saino, T., and Tsuda, A.: Responses of phytoplankton and heterotrophic bacteria in the northwest subarctic Pacific to in situ iron fertilization as estimated by HPLC pigment analysis and flow cytometry, Prog. Oceanogr., 64, 167-187, 2005.

Suzuki, K., Saito, H., Isada, T., Hattori-Saito, A., Kiyosawa, H., Nishioka, J., McKay, R. M., Kuwata, A., and Tsuda, A.: Community structure and photosynthetic physiology of phytoplankton in the northwest subarctic Pacific during an in situ iron fertilization experiment (SEEDS-II), Deep-Sea Res. Pt. II, 56, 2733-2744, 2009.

Trees, C., Clark, D., Bidigare, R., Ondrusek, M., and Mueller, J.: Accessory Pigments versus Chlorophyll a concentrations within the Euphotic Zone: A Ubiquitous Relationship, Limnol. Oceanogr., 45, 1130-1143, 2000.

Uitz, J., Claustre, H., Morel, A., and Hooker, S.: Vertical distribution of phytoplankton communities in open ocean: An assessment based on surface chlorophyll, J. Geophys. Res., 111, C08005, doi:10.1029/2005JC003207, 2006.

Van den Meersche, K., Soetaert, K., and Middelburg, J.: A Bayesian compositional estimator for microbial taxonomy based on biomarker, Limnol. Oceanogr.-Meth., 6, 190-199, 2008.

Van Heukelem, L. and Thomas, C. S.: Computer-assisted highperformance liquid chromatography method development with applications to the isolation and analysis of phytoplankton pigments, J. Chromatogr. A, 910, 31-49, 2001

Van Heukelem, L. and Hooker, S. B.: The importance of a quality assurance plan for method validation and minimizing uncertainties in the HPLC analysis of phytoplankton pigments, in: Phytoplankton Pigments: Characterization, Chemotaxonomy and Applications in Oceanography, edited by: Roy, S., Llewellyn, C., Egeland, E., and Johnsen, G., Cambridge University Press, 2011.

Vidussi, F., Claustre, H., Bustillos-Guzman, J., Cailliau, C., and Marty, J. C.: Determination of chlorophylls and carotenoids of 
marine phytoplankton : separation of chlorophyll a from divinylchlorophyll $a$ and zeaxanthin from lutein, J. Plankton Res., 18, 2377-2382, 1996.

Vidussi, F., Claustre, H., Manca, B., Luchetta, A., and Marty, J.-C.: Phytoplankton pigment distribution in relation to upper thermocline circulation in the eastern Mediterranean Sea during winter, J. Geophys. Res., 106, 939-956, 2001.

Wasmund, N.: Pigment concentration on bottle station BS960823.KTS_290, doi:10.1594/PANGAEA.399756, 39975861, 2006.

Williams, R. and Claustre, H.: Chlorophylls and carotenoids as biomarkers of populations and processes involved in the transformation of the particulate organic matter at the biotrans site (45 ${ }^{\circ}$ N, $\left.18^{\circ} \mathrm{W}\right)$, Deep-Sea Res. Pt. II, 38, 347-355, 1991.
Weber, T. and Deutsch, C.: Ocean nutrient ratios governed by plankton biogeography, Nature, 467, 550-554, 2010.

Weber, T. and Deutsch, C.: Oceanic nitrogen reservoir regulated by plankton diversity and ocean circulation, Nature, 489, 419-422, 2012.

Wright, S., van den Enden, R., Pearce, I., Davidson, A., Scott, F., and Westwood, K.: Phytoplankton community structure and stocks in the Southern Ocean $\left(30-80^{\circ} \mathrm{E}\right)$ determined by CHEMTAX analysis of HPLC pigment signatures, Deep-Sea Res. Pt. II, 57, 758-778, 2010.

Yoder, J., McClain, C., Feldman, G., and Esaias, W.: Annual cycles of phytoplankton chlorophyll in the global ocean: A satellite view, Global Biogeochem. Cy., 7, 181-193, 1993. 